(2) Open Access Full Text Article

\title{
Incorporating medical leadership and management into the UK undergraduate medical curriculum
}

This article was published in the following Dove Press journal:

Advances in Medical Education and Practice

7 August 2015

Number of times this article has been viewed

\section{Elliott Yann Ah-kee' \\ Aamir Asif Khan ${ }^{2}$ \\ 'Monklands Hospital, Airdrie, ${ }^{2}$ Glasgow Royal Infirmary, Glasgow, UK}

Correspondence: Elliott Yann Ah-kee Monklands Hospital, Monkscourt Avenue, Airdrie, North Lanarkshire, ML6 0JS, UK Email elliottahkee@gmail.com

\section{Dear editor}

We read with high interest the letter by Singh et al ${ }^{1}$ which advocates a mandatory year studying for a BSc in management, within the UK undergraduate medical curriculum. The authors have supported their proposition with compelling figures from a recent National Health Service (NHS) report, which is expecting a $£ 30$ billion funding gap by $2020 / 2021$.

We strongly believe that nowadays, leadership and management skills are crucial within the NHS and have been shown to positively impact the overall performance of doctors appointed to hospital boards of directors and clinical outcomes. ${ }^{2}$ Furthermore, we agree with the authors that a lack of knowledge of the NHS structure can be efficiently addressed by incorporating medical leadership and management (MLM) early during undergraduate training.

However, we believe that a mandatory year studying management within an already overcrowded undergraduate curriculum is not realistic and feasible. Moreover, several identified barriers to the implementation of such education, including negative attitudes held by both doctors and students toward MLM still need to be addressed. ${ }^{2}$

Different teaching initiatives have previously been implemented with varying degrees of success, but MLM education still lacks consistency and current literature on how to incorporate this into the undergraduate curriculum, is scarce. ${ }^{3}$

In a recent national survey of UK medical school faculties and students, Stringfellow et $a l^{3}$ reported that over $70 \%$ valued the importance of MLM within the curriculum, hence creating a foundation for education. In addition, the study investigated potential methods of teaching and assessment that could be used for MLM incorporation in undergraduate training. Preferred methods included experiential learning or simulation, quality improvement projects, and student audits. The study concluded that curriculum changes could be achieved by devising new competencies for future editions of General Medical Council's “Tomorrow's Doctors". This could require input from professional bodies, including the General Medical Council, Faculty of Medical Leadership and Management, and NHS Leadership Academy.

In conclusion, we would also like to highlight the importance of MLM within the UK undergraduate medical curriculum. However, further work is required to implement a nationally cohesive MLM program that is evidence-based, in UK medical schools. 


\section{Disclosure}

The authors have no conflicts of interest to disclose.

\section{References}

1. Singh B, Ramjeeawon N, Shah N, Singagireson S. Should an iBSc in Management be compulsory for all UK medical students? Adv Med Educ Pract. 2015;6:383-384.
2. Quince T, Abbas M, Murugesu S, et al. Leadership and management in the undergraduate medical curriculum: a qualitative study of students' attitudes and opinions at one UK medical school. BMJ Open. 2014; 4(6): 005353.

3. Stringfellow TD, Rohrer RM, Loewenthal L, et al. Defining the structure of undergraduate medical leadership and management teaching and assessment in the UK. Med Teach. 2014:1-8.

Dove Medical Press encourages responsible, free and frank academic debate. The content of the Advances in Medical Education and Practice 'letters to the editor' section does not necessarily represent the views of Dove Medical Press, its officers, agents, employees, related entities or the Advances in Medical Education and Practice editors. While all reasonable steps have been taken to confirm the content of each letter, Dove Medical Press accepts no liability in respect of the content of any letter, nor is it responsible for the content and accuracy of any letter to the editor.

Advances in Medical Education and Practice

Dovepress

\section{Publish your work in this journal}

Advances in Medical Education and Practice is an international, peerreviewed, open access journal that aims to present and publish research on Medical Education covering medical, dental, nursing and allied health care professional education. The journal covers undergraduate education, postgraduate training and continuing medical education including emerging trends and innovative models linking education, research, and health care services. The manuscript management system is completely online and includes a very quick and fair peer-review system. Visit http://www.dovepress.com/testimonials.php to read rea quotes from published authors.

Submit your manuscript here: http://www.dovepress.com/advances-in-medical-education-and-practice-journal 